\title{
THE INTERNATIONAL PERMAFROST ASSOCIATION'S CONTRIBUTION TO THE INTERNATIONAL POLAR YEAR
}

JERRY BROWN ${ }^{1}$

Four coordinated permafrost programs were approved by the Joint Committee of the International Polar Year:

1. Permafrost Observatory Project: A Contribution to the Thermal State of Permafrost (\#50 TSP);

2. Antarctic and sub-Antarctic Permafrost, Periglacial and Soil Environments (\#33 ANTPAS);

3. Arctic Circum-Polar Coastal Observatory Network (\#90 ACCO-Net); and

4. Carbon Pools in Permafrost Regions (\#373 CAPP).

Other permafrost activities include regional mapping projects in Central Asia and the Nordic region, education, outreach and data management activities (Brown and Christiansen 2006). The Permafrost Young Researchers Network (PYRN) with over 500 members in 40 countries, encourages the development of a new generation of permafrost researchers. A catalogue of International University Courses on Permafrost (IUCP) list over 135 courses in 17 countries (Christiansen et al., 2007). Our collective permafrost legacy for IPY is to develop an international network of permanent permafrost observatories, establish a sustainable data system, and help develop the next generation of permafrost researchers.

The International Permafrost Association (IPA), with its 26 national members, has taken the lead in organizing regional and bipolar programs to improve our current understanding of the state and fate of permafrost, soils, and periglacial processes throughout the polar and high elevation regions of Planet Earth. Although permafrost temperature observations were made throughout the last century and continue to the present, many locations with excellent past records have been abandoned and some regions are under represented. Warming since the late 1970s has been observed in permafrost temperature profiles from many locations in the Northern Hemisphere; parts of Alaska, Canada, Central Asia, northern Russia, and mid- and low-latitude mountain regions (Brown and Romanovsky 2008, Romanovsky et al. 2008).

The anniversary for International Polar Year (IPY) provided an opportunity for development and implementation of a broad range of permafrost research and monitor-

1 President International Permafrost Association, Woods Hole, MA. E-mail: jerrybrown@igc.org 
ing activities. The International Permafrost Association (IPA) and its working groups and international partners are coordinating these four IPY permafrost projects that include more than 30 individual projects with over 200 individuals representing all IPA member countries. National programs in North America, Europe, and Russia have initiated financial support of specific activities.

The Permafrost Observatory Project: A Contribution to the Thermal State of Permafrost (TSP) is developing a spatially distributed set of observations on the past and present status of permafrost temperatures and active layer thicknesses. There are approximately 550 boreholes listed in the on-line GTN-P network (www.gtnp.org) with most boreholes between 10 and $125 \mathrm{~m}$ deep and located in the Northern Hemisphere (fig. 1), and a smaller number of existing and planned boreholes located in the Antarctic and Subantarctic. New boreholes have been drilled recently throughout the network and others are planned. A second bipolar program, the Circumpolar Active Layer Monitoring (CALM) network, currently has over 160 sites with some sites having data extending back to several decades and more (fig. 2, Nelson et al. 2008).

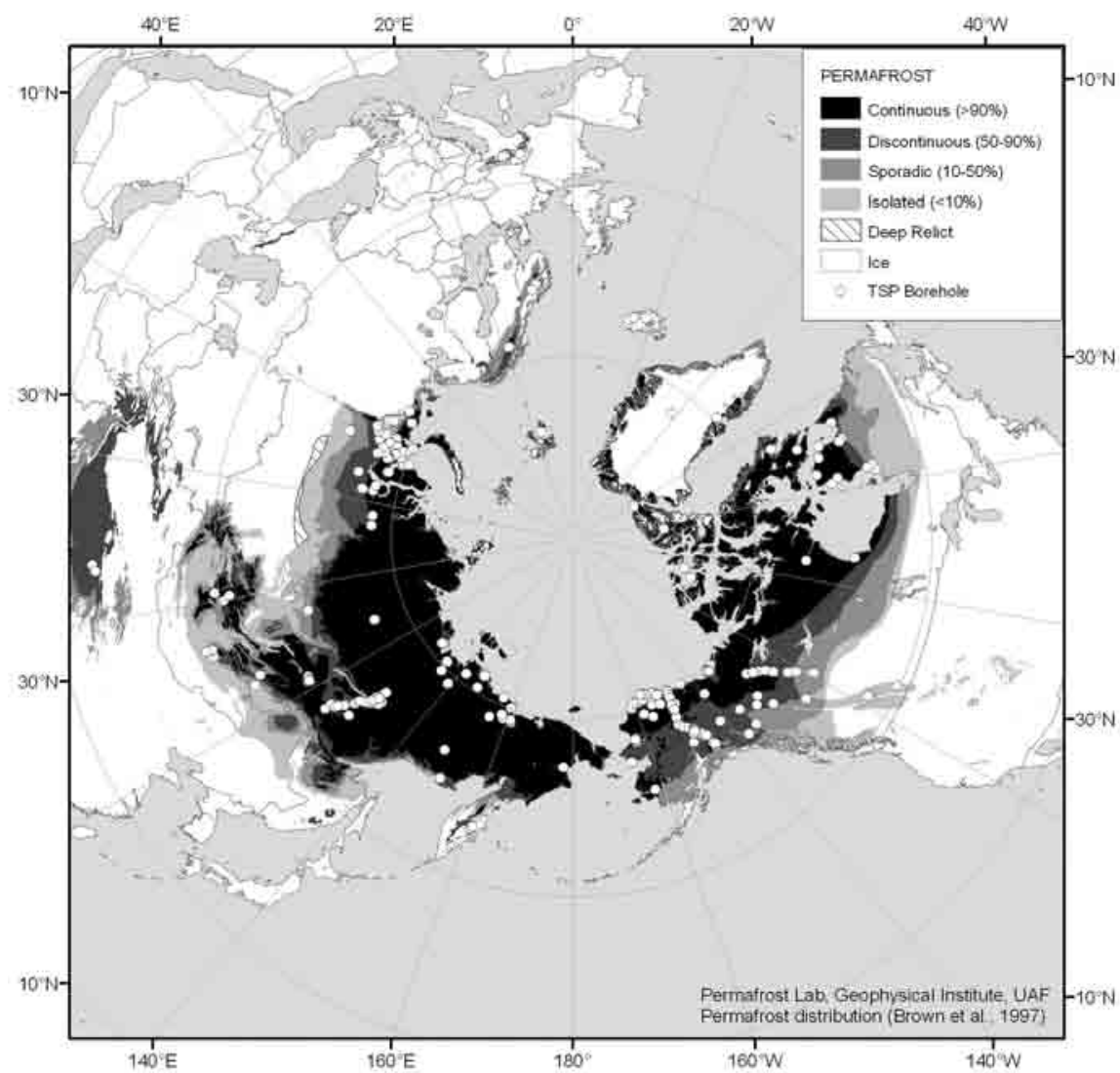

Fig. 1 - Northern Hemisphere permafrost monitoring boreholes included in the TSP project.

Fig. 1 - Sondagens de monitorização das temperaturas do permafrost localizadas no Hemisfério Norte e integradas no projecto TSP. 


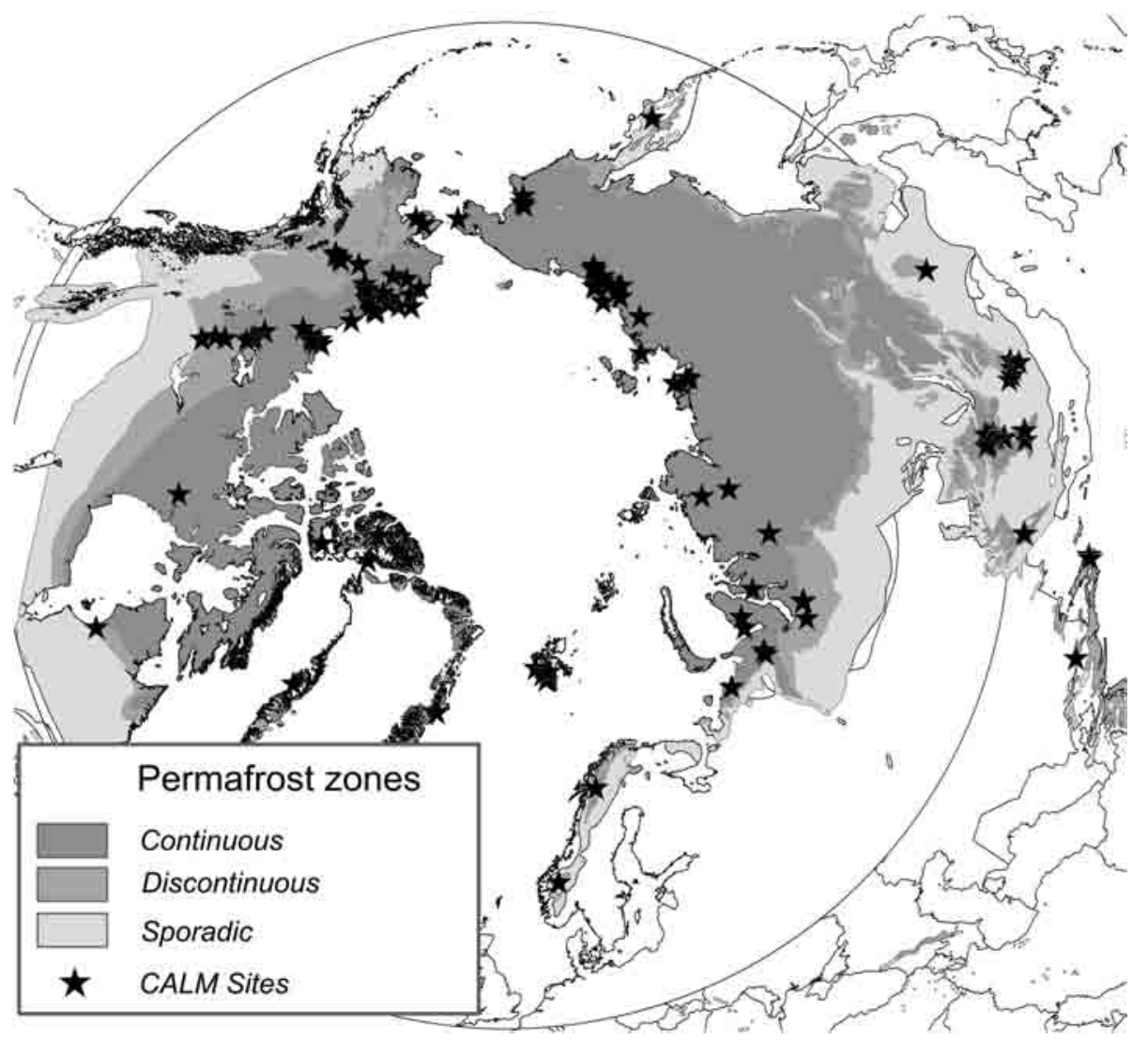

Fig. 2 - Circumpolar Active Layer Monitoring network (CALM) sites in the Northern Hemisphere.

Fig. 2 - Sítios de monitorização da camada activa inseridos na rede Circumpolar Active Layer Monitoring Network (CALM).

Other projects under the Permafrost Observatory Project include paleo-reconstruction of permafrost formation, field and laboratory centrifuge measurements of slope movements (CRYOSLOPE), thermal response of permafrost following disturbances, and design and performance of transportation infrastructures (TIP). The last three have engineering and geotechnical elements. Our long-term goal is that this IPY Permafrost Observatory Project will results in the development of a permanent International Network of Permafrost Observatories (INPO).

The Antarctic and sub-Antarctic Permafrost, Periglacial and Soil Environments Project (ANTPAS) is aimed at integrating existing and new data on the distribution, thickness, age, history and physical and geochemical properties of permafrost, soils and the active-layer on the Antarctic continent and sub-Antarctic islands. A monitoring network, a regional subset of GTN-P and consisting of borehole temperatures, activelayer thickness, and periglacial observations, will be established along selected environ- 
mental gradients. Fourteen countries are involved in ANTPAS. http://erth.waikato.ac. nz/antpas/

The Arctic Circum-Polar Coastal Observatory Network (ACCO-Net) is developing a coordinated monitoring program incorporating diverse regions and providing site-specific, fine-scale baseline and time-series data. The project is an extension of the highly successful Arctic Coastal Dynamics project. An internationally coordinated circum-Arctic network of coastal and marginal seas observatories is planned. Five countries are involved in ACCO. http://www.awi-potsdam.de/acd/acconet/

The Carbon Pools in Permafrost Regions (CAPP) project is aimed at quantifying soil organic matter quantity and quality in high-latitude and high-altitude regions that are characterized by the presence of isolated to continuous permafrost terrain. Special attention is given to the widespread peatlands (organic soils). CAPP plans to contribute to new research activities along high-latitude transects in the Northern Hemisphere that represent the range of ecoclimatic and permafrost regions, complemented by two transects in the Subantarctic-Antarctic region, and additional altitudinal transects in high-alpine environments. www.geowiss.uni-hamburg.de/i-boden.capp/

Although national maps exist for China, Kazakhstan, Mongolia and southern Russia, there are no consistent cartographic criteria or terminology on which to base a unified permafrost map of Central Asia for these topographically complex and diverse regions. A project was undertaken to develop an international cartographic classification and to derive map products to represent permafrost conditions in the high-elevation regions of Central Asia. A second project is underway to map permafrost distribution and estimate the lower limits of permafrost in the Nordic region.

Educational, outreach and data management activities are key elements for all IPY activities. Data sharing and accessibility is an important element and the IPA projects are adhering to these IPY policies. International classroom and field activities for primary and secondary schools are taking places in many countries. The Permafrost Young Researchers Network was developed to facilitate and strengthen contacts and communications among young scientists and engineers in the permafrost community and to provide information on availability of fellowships, conference travel opportunities, job opportunities, and current developments. Membership of students and young professionals is encouraged. www.awi-potsdam.de/pyrn/

The IPA is coordinating these IPY approved projects in cooperation with the International Union of Geological Sciences (IUGS), the Scientific Committee for Antarctic Research (SCAR), the WCRP Climate and Cryosphere (CliC), the Global Carbon Project, the Land-Ocean Interactions in the Coastal Zone (LOICZ) and the International Arctic Science Committee (IASC).

To summarize, our IPY permafrost "legacies" are to:

1. Encourage the development of a new generation of researchers;

2. Produce the "snapshot" of existing permafrost conditions as a sustainable database for future change assessment; and

3. Establish a permanent International Network of Permafrost Observatories.

Data sharing and accessibility is an important element of the IPY and the IPA will adhere to these policies. A series of field courses are available and young researchers are developing their own borehole measurement sites. Initial results of these IPY activities are being reported during summer 2008 at the Ninth International Conference on 
Permafrost (NICOP) in Fairbanks, Alaska, as the IPA celebrates its $25^{\text {th }}$ anniversary and the $125^{\text {th }}$ anniversary of the IPY, and at the $33^{\text {rd }}$ International Geological Congress in Oslo, Norway.

\section{REFERENCES}

Brown J, Christiansen H H (2006) Report from the International Permafrost Association. Permafrost and Periglacial Processes, 17: 377-379.

Brown J, Romanovsky V E (2008) Report from the International Permafrost Association: State of Permafrost in the First Decade of the 21st Century. Permafrost and Periglacial Processes, 19: 255-260.

Christiansen H H, Prick A, Lantuit H (2007) The International Permafrost Association - education and outreach for the International Polar Year. Permafrost and Periglacial Processes, 18: 209213.

Nelson F E, Shiklomanov N I, Hinkel K M, Brown J (2008) Decadal Results from the Circumpolar Active Layer Monitoring (CALM) Program. Proceedings Ninth International Conference on Permafrost, Fairbanks, Alaska.

Romanovsky V E, et al. (2008) Thermal state and fate of permafrost in Russia. First Results of IPY. Proceedings Ninth International Conference on Permafrost. Fairbanks, Alaska. 